\title{
Influence of Fertilizer Levels on the Growth and Yield of Black Cumin (Nigella sativa L.)
}

\author{
M. M. K. Ali*, M. A. Hasan and M. R. Islam \\ Department of Crop Physiology and Ecology, Hajee Mohammad Danesh Science and Technology \\ University, Dinajpur, Bangladesh \\ *Corresponding author and Email: muradsarkar7@gmail.com
}

Received: 16 September 2015

Accepted: 12 December 2015

\begin{abstract}
An experiment was conducted at the research farm of Crop Physiology and Ecology Department, Hajee Mohammad Danesh Science and Technology University, Dinajpur, Bangladesh, during November 2013 to April 2014 to determine the growth and yield performance of four varieties of black cumin (Exotic variety, BARI kalozira-1, Faridpur local and Natore local) as influenced by three levels of fertilizers (40-20-30 Kg ha ${ }^{-1}, 80-30-45 \mathrm{Kg} \mathrm{ha}^{-1}$ and 120-40-60 Kg ha ${ }^{-1} \mathrm{~N}-\mathrm{P}-\mathrm{K}$, respectively). The experiment was conducted in a randomized complete block design (RCBD) with three replications. First flower bud initiation day, capsule setting, and capsule ripening in 50\% plant were not significantly influenced by N-P-K fertilizer levels. The secondary branch plant ${ }^{-1}$, tertiary branch plant ${ }^{-}$ 1 , plant height at harvest, capsule length, capsule diameter and 1000 seed weight of black cumin were also not influenced significantly by the fertilizer levels. The dry matter weight plant ${ }^{-1}$, primary branch plant $^{-1}$, fruit plant $^{-1}$, seed capsule ${ }^{-1}$ and grain yield of black cumin genotypes were significantly influenced by different levels of N-P-K fertilizers. Natore local gave maximum dry matter production plant $^{-1}$ at 55 DAS with moderate N-P-K levels and at 70 DAS with higher N-P-K fertilizer levels (0.22 and $1.06 \mathrm{~g}$, respectively), whereas Exotic black cumin genotype showed maximum dry matter plant $^{-1}$ at 85 and 100 DAS with higher N-P-K fertilizer levels (2.30 and $4.97 \mathrm{~g}$, respectively). Exotic variety produced maximum grain yield $\left(3.43 \mathrm{~g} \mathrm{plant}^{-1}\right.$ and $2.30 \mathrm{t} \mathrm{ha}^{-1}$ ) at higher level of N-P-K fertilizer, but BARI kalozira-1 (2.95 $\mathrm{g} \mathrm{plant}^{-1}$ and $\left.1.95 \mathrm{t} \mathrm{ha}^{-1}\right)$, Faridpur local $\left(2.80 \mathrm{~g} \mathrm{plant}^{-1}\right.$ and $1.90 \mathrm{t}$ $\mathrm{ha}^{-1}$ ) and Natore local (2.69 $\mathrm{g} \mathrm{plant}^{-1}$ and $1.80 \mathrm{t} \mathrm{ha}^{-1}$ ) showed maximum yields at moderate N-P-K fertilizer levels. Among the test varieties of black cumin, the exotic variety showed better yield performance than the others.
\end{abstract}

Keywords: N-P-K-fertilizer, growth, yield, black cumin

\section{Introduction}

Black cumin (Nigella sativa L.) is an important spice crop known as 'Kalozira' in Bangladesh and is cultivated in the winter season. It is grown in Mediterranean region and is widely cultivated throughout Syria, Egypt, Iran, Iraq and Turkey
(Al-Dagawi, 1996). In Bangladesh, it is grown well in Faridpur, Sariatpur, Madaripur, Pabna, Sirajganj, Jessore, Kusthtia and Natore districts. Black cumin is extensively used in traditional medicine. Whole seeds or their extracts have antidiabetic, antihistaminic, antihypertensive, anti-inflammatory, antimicrobial, antitumor, 
galactagogue and insect repellent effects. The amount of nutrient uptake depends on the quality of capsule and dry matter they produce, which in turn is influenced by a number of genetic and environmental factors (Shukla and Naik, 1993).

Nitrogen has the largest effect on plant physiology and is probably the most important limiting nutrient for crop growth. Agricultural soils are often deficient in $\mathrm{N}$ and hence, to ensure adequate $\mathrm{N}$ supply to crops and to prevent from nutrient deficiencies, large amounts of inorganic $\mathrm{N}$ are applied (Shah, 2004). Phosphorus in the soil has developmental activity in the plant's root growth. Depending on phosphorus applications, the contact area of the root expands with the growth of root which, in turn, gives values in the range of $30.7 \mathrm{~cm}$ and $35.3 \mathrm{~cm}$ in black cumin (Geren et al., 1997). Potassium fertilizer is another essential component to reduce the severity of disease of black cumin plants. Application of $30 \mathrm{~kg} \mathrm{~K} \mathrm{ha}^{-1}$ along with $30 \mathrm{~kg} \mathrm{~N}$ $\mathrm{ha}^{-1}$ decreased plant death due to disease and also increased yield in Cumin (Champawat and Pathak, 1982). Very cool temperature and excessive use of fertilizer may cause reduction in growth and yield of black cumin and increase diseases infestation. Black cumin of different genotypes requires good combination of fertilizers for optimum growth and yield. The present study was undertaken to understand the growth and yield of black cumin genotypes under different levels of N-P-K fertilizer and also to determine the optimum fertilizer doses for black cumin production.

\section{Materials and Methods}

The experiment was set-up at the research farm of Crop Physiology and Ecology Department, Hajee Mohammad Danesh Science and Technology University, Dinajpur, Bangladesh during November 2013 to April 2014. The experiment was laid out in a two factors randomized complete block design (RCBD) with three replications. One factor consisted of four genotypes (Exotic variety, BARI kalozira-1,
Faridpur local and Natore local) and the other factor consisted of three fertilizer levels (Low, moderate and high level of N-P-K as 40-20-30 $\mathrm{Kg} \mathrm{ha}^{-1}, 80-30-45 \mathrm{Kg} \mathrm{ha}^{-1}$ and 120-40-60 Kg ha1 , respectively). The individual experimental plot was first divided into three blocks each representing a replication. Each block was then divided into twelve-unit plots of $1.0 \mathrm{~m} \times 1.2 \mathrm{~m}$ size. The distance between blocks was $1.0 \mathrm{~m}$ and between plots was $0.5 \mathrm{~m}$.

Seeds were soaked in water for 24 hours to facilitate germination. They were dried and treated by Bavistin (carbendazim) @ $2 \mathrm{~g} \mathrm{~kg}^{-1}$ seeds to minimize the primary seed-borne disease. The seeds were mixed with some loose soil to allow uniform sowing in rows and were sown in rows $15 \mathrm{~cm}$ apart, at the rate of $10 \mathrm{~kg}$ $\mathrm{ha}^{-1}$ at about a depth of one $\mathrm{cm}$. Continuous line was done to maintain plant to plant distance of $10 \mathrm{~cm}$ by thinning after 15 days. The seeds were covered with loose soil properly just after sowing and gently pressed by hands. The sowing was done November 19, 2013 with slight watering to enhance proper germination.

Five fresh plants were selected from each plot for sampling at different days after sowing. Dry matter weight at different days after showing, Days of first flower bud initiation, capsule setting, and capsule ripening in $50 \%$ plant were recorded. Number of branches plant ${ }^{-1}$, plant height, capsule length, capsule diameter, fruits plant $^{-1}$, seed capsule ${ }^{-1}, 1000$ seed weight and yield were also recorded. The data were analyzed by partitioning the total variance with the help of computer by using MSTAT program. The treatment means were compared using Duncan's Multiple Range Test (DMRT) at $\mathrm{P} \leq 5 \%$ level.

\section{Results and Discussion}

\subsection{Dry matter weight plant ${ }^{-1}$}

Dry matter weight plant $^{-1}$ of black cumin genotypes were significantly influenced by the fertilizer levels (Figure 1). Dry matter weight plant $^{-1}$ was increased gradually with the higher 
level of applied fertilizer. Among the treatment combinations Natore local variety produced the maximum dry matter weight $(0.22 \mathrm{~g})$ at 55 DAS with moderate level of fertilizers, whereas the exotic variety produced minimum dry matter weight $(0.1 \mathrm{~g})$ with lower level of fertilizer. At 70 DAS, maximum dry matter weight $(1.06 \mathrm{~g})$ was recorded in Natore local varity with higher level of fertilizer, whereas minimum dry matter weight $(0.46 \mathrm{~g})$ was recorded in Exotic variety with lower level of fertilizers. At 85 DAS, the maximum dry matter weight $(2.3 \mathrm{~g})$ was observed in the exotic variety with higher level of fertilizer whereas the minimum dry matter weight $(0.82 \mathrm{~g})$ was obtained in BARI kalozira-1 variety with lower level of fertilizer. At 100 DAS, the exotic variety with higher level of fertilizer provided the maximum dry matter weight (4.97 g/plant) whereas the same variety with lower level of fertilizer showed the minimum dry matter weight (2.02 g).

\subsection{First flower bud initiation, Capsule setting and capsule ripening days in $50 \%$ plant}

Fertilizer levels did not influence the first flower bud initiation day in $50 \%$ plants of black cumin genotypes (Table 1). Among the tested variety the exotic variety with lower level of fertilizer took the maximum days ( 82.00 days) for first flower bud initiation in $50 \%$ plants, whereas Faridpur local variety with higher level of fertilizer took the minimum days (76 days). Capsule setting days in $50 \%$ plant did not differ significantly under different levels of fertilizers (Table 1).

Exotic variety with lower fertilizer level took the longest time (86 days) for capsule setting in 50\% plant, whereas Faridpur local variety with higher fertilizer level took the shortest time (78 days). Capsule ripening time in $50 \%$ plant did not differ significantly under different levels of fertilizers (Table 1). Among the treatment combinations, Exotic variety with higher level of fertilizer took minimum time (134 day) for capsule setting in $50 \%$ plant, whereas Natore local variety with moderate level of fertilizer expressed the minimum time (131 days).

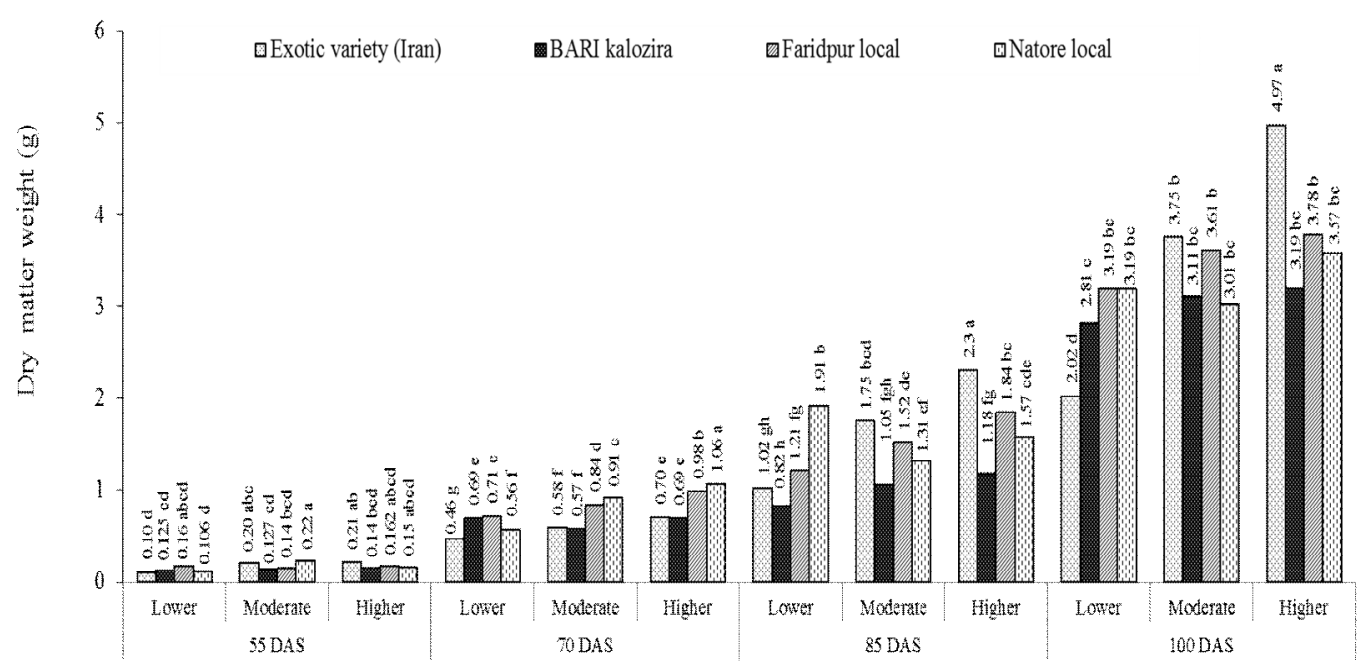

Fertilizer levels

Figure 1. Effect of fertilizer on dry matter weight plant ${ }^{-1}$ of different black cumin genotypes at different days after sowing. (Means followed by different letter (s) at specific days after sowing differed significantly by DMRT at $\mathrm{P} \leq 5 \%$ ) 
Table 1. Effect of fertilizer on first flower bud initiation, capsule setting and capsule ripening days in $50 \%$ plant of different black cumin genotypes

\begin{tabular}{lcccc}
\hline Genotypes & $\begin{array}{c}\text { Fertilizer levels } \\
\text { N:P:K }\left(\mathrm{kg} \mathrm{ha}^{-1}\right)\end{array}$ & $\begin{array}{c}\text { First flower bud } \\
\text { initiation days in } \\
50 \% \text { plant }\end{array}$ & $\begin{array}{c}\text { Capsule setting } \\
\text { days in 50\% } \\
\text { plant }\end{array}$ & $\begin{array}{c}\text { Capsule ripening } \\
\text { days in 50\% plant }\end{array}$ \\
\hline Exotic variety & $40: 20: 30$ & 82.00 & 86.33 & 133.00 \\
(Iran) & $80: 30: 45$ & 78.00 & 83.33 & 132.33 \\
& $120: 40: 60$ & 79.00 & 84.00 & 134.00 \\
\cline { 2 - 5 } BARI kalozira-1 & $40: 20: 30$ & 77.67 & 82.33 & 133.00 \\
& $80: 30: 45$ & 78.00 & 82.67 & 133.33 \\
& $120: 40: 60$ & 77.00 & 81.33 & 132.33 \\
Faridpur local & $40: 20: 30$ & 77.67 & 80.67 & 133.00 \\
& $80: 30: 45$ & 77.00 & 80.33 & 132.67 \\
Natore local & $120: 40: 60$ & 76.00 & 79.67 & 132.33 \\
\hline CV (\%) & $40: 20: 30$ & 77.33 & 80.67 & 131.33 \\
Level of & $80: 30: 45$ & 77.67 & 80.67 & 131.00 \\
significance & $120: 40: 60$ & 77.67 & 80.67 & 131.67 \\
\hline
\end{tabular}

Means followed by different letter (s) within a parameter differed significantly by DMRT at $\mathrm{P} \leq 5 \%$.

Table 2. Effect of fertilizer on branch plant ${ }^{-1}$ at harvest of different black cumin genotypes

\begin{tabular}{lcccc}
\hline Genotypes & $\begin{array}{c}\text { Fertilizer levels } \\
\text { N:P:K }\left(\mathrm{kg} \mathrm{ha}^{-1}\right)\end{array}$ & $\begin{array}{c}\text { Primary branch } \\
\text { plant }^{-1}\end{array}$ & $\begin{array}{c}\text { Secondary branch } \\
\text { plant }^{-1}\end{array}$ & $\begin{array}{c}\text { Tertiary branch } \\
\text { plant }^{-1}\end{array}$ \\
\hline Exotic variety & $40: 20: 30$ & $5.27 \mathrm{~cd}$ & 5.73 & 12.33 \\
(Iran) & $80: 30: 45$ & $5.67 \mathrm{bc}$ & 8.43 & 18.10 \\
& $120: 40: 60$ & $6.87 \mathrm{a}$ & 8.80 & 20.23 \\
\cline { 2 - 5 } BARI kalozira-1 & $40: 20: 30$ & $4.60 \mathrm{~d}$ & 5.40 & 11.23 \\
& $80: 30: 45$ & $5.40 \mathrm{~cd}$ & 6.74 & 17.73 \\
& $120: 40: 60$ & $5.13 \mathrm{~cd}$ & 6.27 & 16.35 \\
\cline { 2 - 5 } Faridpur local & $40: 20: 30$ & $4.60 \mathrm{~d}$ & 5.93 & 10.92 \\
& $80: 30: 45$ & $6.07 \mathrm{abc}$ & 8.00 & 16.62 \\
& $120: 40: 60$ & $6.47 \mathrm{ab}$ & 7.00 & 15.36 \\
Natore local & $40: 20: 30$ & $5.40 \mathrm{~cd}$ & 5.93 & 10.00 \\
& $80: 30: 45$ & $6.11 \mathrm{abc}$ & 7.67 & 15.44 \\
\hline CV $(\%)$ & $120: 40: 60$ & $5.40 \mathrm{~cd}$ & 6.67 & 14.34 \\
Level of & & 7.43 & 12.38 & 12.32 \\
significance & & $* *$ & $\mathrm{NS}$ & $\mathrm{NS}$ \\
\hline
\end{tabular}

Means followed by different letter (s) within a parameter differed significantly by DMRT at $\mathrm{P} \leq 5 \%$. 
Table 3. Effect of fertilizer on plant height, capsule length and capsule diameter at harvest of different black cumin genotypes

\begin{tabular}{lcccc}
\hline \multirow{2}{*}{ Genotypes } & $\begin{array}{c}\text { Fertilizer levels } \\
\mathrm{N}: \mathrm{P}: \mathrm{K}\left(\mathrm{kg} \mathrm{ha}^{-1}\right)\end{array}$ & $\begin{array}{c}\text { Plant height at } \\
\text { harvest }\end{array}$ & $\begin{array}{c}\text { Capsule length } \\
(\mathrm{cm})\end{array}$ & $\begin{array}{c}\text { Capsule } \\
\text { diameter }(\mathrm{cm})\end{array}$ \\
\hline Exotic variety & $40: 20: 30$ & 48.00 & 1.02 & 0.74 \\
(Iran) & $80: 30: 45$ & 52.20 & 1.13 & 0.80 \\
& $120: 40: 60$ & 59.69 & 1.17 & 0.82 \\
\cline { 2 - 5 } BARI kalozira-1 & $40: 20: 30$ & 46.20 & 1.00 & 0.72 \\
& $80: 30: 45$ & 49.47 & 1.10 & 0.75 \\
& $120: 40: 60$ & 48.87 & 1.08 & 0.74 \\
\cline { 2 - 5 } Faridpur local & $40: 20: 30$ & 50.13 & 0.99 & 0.71 \\
& $80: 30: 45$ & 55.60 & 1.02 & 0.77 \\
& $120: 40: 60$ & 53.94 & 1.00 & 0.75 \\
Natore local & $40: 20: 30$ & 46.60 & 0.98 & 0.70 \\
& $80: 30: 45$ & 49.87 & 1.00 & 0.74 \\
\hline CV $(\%)$ & $120: 40: 60$ & 48.53 & 0.99 & 0.73 \\
Level of & & 8.57 & 6.15 & 3.90 \\
significance & & $\mathrm{NS}$ & $\mathrm{NS}$ & $\mathrm{NS}$ \\
\hline
\end{tabular}

Means followed by different letter (s) within a parameter differed significantly by DMRT at $\mathrm{P} \leq 5 \%$.

Table. 4. Effect of fertilizer on yield components and grain yield at harvest of different black cumin genotypes

\begin{tabular}{|c|c|c|c|c|c|c|}
\hline Genotypes & $\begin{array}{l}\text { Fertilizer levels } \\
\text { N:P:K }\left(\mathrm{kg} \mathrm{ha}^{-1}\right)\end{array}$ & $\begin{array}{c}\text { Capsule plant } \\
\text { at harvest }\end{array}$ & $\begin{array}{c}\text { Seeds } \\
\text { capsule }^{-1}\end{array}$ & $\begin{array}{l}1000 \text { seed } \\
\text { weight }(\mathrm{g})\end{array}$ & $\begin{array}{c}\text { Yield } \\
\left(\text { g plant }^{-1}\right)\end{array}$ & $\begin{array}{l}\text { Yield } \\
\left(\mathrm{t} \mathrm{ha}^{-1}\right)\end{array}$ \\
\hline \multirow{3}{*}{$\begin{array}{l}\text { Exotic } \\
\text { variety } \\
\text { (Iran) }\end{array}$} & $40: 20: 30$ & $15.45 \mathrm{bc}$ & $74.53 \mathrm{~d}$ & 2.17 & $2.90 \mathrm{~cd}$ & $1.90 \mathrm{~cd}$ \\
\hline & $80: 30: 45$ & $17.00 \mathrm{ab}$ & $80.87 \mathrm{bcd}$ & 2.30 & $3.19 \mathrm{~b}$ & $2.10 \mathrm{~b}$ \\
\hline & $120: 40: 60$ & $18.28 \mathrm{a}$ & $99.13 \mathrm{a}$ & 2.35 & $3.43 \mathrm{a}$ & $2.30 \mathrm{a}$ \\
\hline \multirow{3}{*}{$\begin{array}{l}\text { BARI } \\
\text { kalozira-1 }\end{array}$} & $40: 20: 30$ & $10.58 \mathrm{e}$ & $77.13 \mathrm{~cd}$ & 2.10 & $2.17 \mathrm{~g}$ & $1.45 \mathrm{~g}$ \\
\hline & $80: 30: 45$ & $14.38 \mathrm{~cd}$ & $82.00 \mathrm{bcd}$ & 2.34 & $2.95 \mathrm{c}$ & $1.95 \mathrm{bc}$ \\
\hline & $120: 40: 60$ & $13.06 \mathrm{~d}$ & $80.60 \mathrm{bcd}$ & 2.28 & $2.68 \mathrm{de}$ & $1.75 \mathrm{de}$ \\
\hline \multirow{3}{*}{$\begin{array}{l}\text { Faridpur } \\
\text { local }\end{array}$} & $40: 20: 30$ & $10.10 \mathrm{e}$ & $77.93 \mathrm{~cd}$ & 2.09 & $2.30 \mathrm{fg}$ & $1.50 \mathrm{fg}$ \\
\hline & $80: 30: 45$ & $14.28 \mathrm{~cd}$ & $88.67 \mathrm{~b}$ & 2.38 & $2.80 \mathrm{~cd}$ & $1.90 \mathrm{~cd}$ \\
\hline & $120: 40: 60$ & $13.67 \mathrm{~d}$ & $87.84 \mathrm{~b}$ & 2.32 & $2.71 \mathrm{cde}$ & $1.80 \mathrm{cde}$ \\
\hline \multirow{3}{*}{$\begin{array}{l}\text { Natore } \\
\text { local }\end{array}$} & $40: 20: 30$ & $10.26 \mathrm{e}$ & $74.07 \mathrm{~d}$ & 2.02 & $2.09 \mathrm{~g}$ & $1.40 \mathrm{~g}$ \\
\hline & $80: 30: 45$ & $13.21 \mathrm{~d}$ & $84.87 \mathrm{bc}$ & 2.27 & $2.69 \mathrm{de}$ & $1.80 \mathrm{cde}$ \\
\hline & $120: 40: 60$ & $11.34 \mathrm{e}$ & $83.07 \mathrm{bcd}$ & 2.25 & 2.49 ef & $1.65 \mathrm{ef}$ \\
\hline $\mathrm{CV}(\%)$ & & 5.28 & 4.59 & 3.30 & 370 & 3.78 \\
\hline \multicolumn{2}{|c|}{ Level of significance } & $* *$ & $* *$ & NS & $* *$ & $* *$ \\
\hline
\end{tabular}

Means followed by different letter ( $\mathrm{s}$ ) within a parameter differed significantly by DMRT at $\mathrm{P} \leq 5 \%$. 


\subsection{Branch plant ${ }^{-1}$}

The number of primary branch plant ${ }^{-1}$ of black cumin was influenced significantly under different level of fertilizer, whereas secondary and tertiary branch plant ${ }^{-1}$ were not influenced significantly (Table 2). Among the treatment combinations, exotic variety with higher fertilizer level produced the maximum number of primary, secondary and tertiary branches plant $^{-1}$ (6.87, 8.80 and 20.23), whereas BARI Kalozira1 with lower fertilizer level showed the minimum primary, secondary and tertiary branch plant $^{-1}$ (4.60, 5.40 and 11.23). Tuncturk et al. (2012) found significant influence of nitrogen levels on the number of branch plant ${ }^{-1}$ in black cumin.

\subsection{Plant height}

Plant height did not vary significantly with different levels of fertilizers at harvest of black cumin (Table 3). The maximum plant height at harvest $(59.69 \mathrm{~cm})$ was observed in Exotic variety with higher level of fertilizer, whereas the minimum plant height at harvest $(46.20 \mathrm{~cm})$ was calculated in BARI Kalozira-1 variety with lower level of fertilizer. Valadabadi and Aliabadi (2011) found plant height of black cumin to range from be 58 to $82 \mathrm{~cm}$. Plant heights might be controlled genetically, and/or environmental factors. The reason may be due to higher doses of nitrogen application which itself increases plant growth by promoting processes such as cell division, cell enlargement, metabolic processes.

\subsection{Capsule length \& diameter}

Capsule lengths of the black cumin genotypes were significantly influenced by the levels of fertilizer (Table 3). Among the treatment combinations, the exotic variety with higher level of fertilizer gave the maximum capsule length at harvest $(1.17 \mathrm{~cm})$, whereas the lowest capsule length at harvest $(0.98 \mathrm{~cm})$ was observed in Natore local variety at lower level of fertilizer. Capsule diameter of different black cumin genotypes were significantly influenced by fertilizer levels and genotypes (Table 3). Among the treatment combinations, the exotic variety with maximum fertilizer level provided the highest capsule diameter $(0.82 \mathrm{~cm})$, whereas Natore local variety with lower fertilizer level showed the minimum capsule diameter $(0.70 \mathrm{~cm})$.

\subsection{Number of capsule plant ${ }^{-1}$ and seed capsule $^{-1}$}

Capsule plant $^{-1}$ at harvest was significantly influenced by the levels of fertilizer (Table 4). Exotic variety with higher level of fertilizer gave the maximum number of fruit plant $^{-1}$ at harvest (18.28) which was statistically similar to that with moderate level of fertilizer. Hammo and AlAtrakchii (2006), Rana et al. (2012) and Tuncturk et al. (2012) also reported increased capsule number plant ${ }^{-1}$ of black cumin with increased fertilizer levels. Number of seed capsule $^{-1}$ of different genotypes were significantly influenced by the level of fertilizers (Table 4). Exotic variety with higher fertilizer level observed the maximum number of seed capsule $^{-1}$ at harvest (99.13), whereas Natore local variety with lower fertilizer level exerted the minimum number of seed capsule ${ }^{-1}$ at harvest (74.07). This result was in partial conformity with the findings of Toncer and Kizil (2004) who reported that, number of seed capsule ${ }^{-1}$ varied from 90.7 to 92.8 .

\subsection{0 seed weight}

1000 seed weight is an important yield contributing character. The 1000 seed weight of black cumin genotypes did not vary significantly with fertilizer level (Table 4). Among the treatment combinations, Faridpur variety with moderate fertilizer level produced the maximum seed weight $(2.38 \mathrm{~g})$, whereas Natore local variety with lower fertilizer level showed minimum seed weight (2.02g). Rana et al. (2012) and Kaheni at el. (2013) also found significant effect of fertilizer levels on thousand seed weight of black cumin.

\subsection{Seed yield}

Seed yields plant ${ }^{-1}$ of black cumin genotypes were significantly influenced by fertilizer levels (Table 4). The maximum yield plant $^{-1}$ (3.43 g) was recorded in exotic variety with higher fertilizer level at harvest. However, other three 
genotypes i.e. BARI kalozira-1 (2.95 g), Faridpur local (2.80 g) and Natore local (2.69 g) showed better performance at moderate fertilizer levels.

Seed yield hectare ${ }^{-1}$ of black cumin genotypes were also significantly influenced by the fertilizer levels (Table 4). The highest yield hectare $^{-1}$ was obtained from exotic variety with higher fertilizer level which was statistically higher than all treatment combinations. The lowest yield hectare ${ }^{-1}(1.40 \mathrm{t})$ was given by Natore local variety at lower fertilizer level. Exotic variety showed increasing grain yield with the increase of fertilizer level with the highest yield $\left(2.30 \mathrm{t} \mathrm{ha}^{-1}\right)$ at higher fertilizer level. The other three genotypes -BARI kalozira1 (1.95 t ha $\left.{ }^{-1}\right)$, Faridpur local $\left(1.90 \mathrm{t} \mathrm{ha}^{-1}\right)$ and Natore local $\left(1.80 \mathrm{t} \mathrm{ha}^{-1}\right)$ showed the better performance at moderate fertilizer level. Valabadi and Aliabadi (2011) found yield of up to $1.43 \mathrm{t} / \mathrm{ha}$. Tuncturk et al. (2012) reported that increasing phosphorus doses positively influenced seed yields in black cumin.

\section{Conclusions}

It may be concluded that different black cumin genotypes responded differently in their growth and yields with the fertilizer levels. The exotic variety gave the maximum grain yield at higher fertilizer level. On the other hand, BARI kalozira-1, Faridpur local and Natore local provided the maximum grain yield at moderate fertilizer levels.

\section{References}

Al-Dagawi A. 1996. Aromatic and medicinal plant introduction encyclopedia. Madboli library. Cairo. Egypt.

Champawat R. S., V. N. Pathak, 1982. Role of nitrogen, Phosphorus and potassium fertilizers and organic amendments in cumin (Cuminum cyminum L.) with incites by Fusarium oxysporum f. sp. cumin. Indian Journal Agricultural of Science, 58 (9): 728-730.

Geren H., E. Bayram and A. Ceylan. 1997. Effect of different sowing dates and phosphorus fertilizer application on the yield and quality characteristics of Blackcumin (Nigella sativa L.). Proceedings of the Second National Field Crops Congress, 376-380 p.

Hammo Y. H. and A. O. Al-Atrakchii. 2006. Effect of nitrogen, phosphorus fertilizers and plant distances on growth of (Nigella sativa L.). 1-Vegetative growth and seed oil production. Mesopotamia Journal of Agriculture, 34(3): 17-26.

Kaheni A., S. H. R. Ramazani, H. R. Ganjali and H. R. Mobaser. 2013. Effect of nitrogen fertilizer and plant density on yield and its components in Cumin (Cuminum cyminum L.) in South Khorasan Province. International Journal of Agriculture Crop Science, 6 (5): 248-251.

Shah S. H. 2004. Morphophysiological response of black cumin (Nigella sativa L.) to nitrogen, gibberellic acid and kinetin application. Ph.D. Thesis, Aligarh Muslim University, Aligarh, India.

Shah S. H. 2006. Photosynthetic and yield responses of Nigella sativa L. to presowing seed treatment with $\mathrm{GA}_{3}$. Turkish Journal of Biology, 31: 103-107.

Shah, S. H. 2011.Gibberellic acid induced amelioration of salt stress in Black cumin (Nigella sativa L.). Genetics and Plant Physiology, 1 (1-2): 65-78.

Shukla V. L. and B. Naik. 1993. Agrotechniques for solanaceous vegetables. In: Advance in Horticulture, vol. 5. Malhotra Publishing House, New Delhi, India Journal of Genetic and Plant Breed, 62(4): 336-337 
Tuncturk R., M. Tuncturk and V. Ciftci, 2012. The Effects of Varying Nitrogen Doses on Yield And Some Yield Components of Black Cumin (Nigella Sativa L.). Yuzuncu Yil University, Faculty of Agriculture, Department of Field Crops, Van, Turkey, Advances in Environmental Biology, 6(2): 855-858.
Toncer O. and S. Kizil. 2004. Effect of seed rate on agronomic and technologies characters of Nigella sativa L. International Journal of Agriculture and Biology, 6(3):529-532.

Valadabadi S. A. and H. F. Aliabadi. 2011. Investigation of bio-fertilizers influence on quantity and quality characteristics in Nigella sativa L. Journal of Horticulture and Forestry, 3 (3):88-92. 